\title{
The Perception of Users on the Modern Interior Design of the Library:
}

\author{
A Case Study in the University of Surabaya Library
}

\author{
Herlina Nur Aisjah* \\ Student at Department of Library Science \\ University of Wijaya Kusuma Surabaya \\ Surabaya, Indonesia \\ *herlinanurais20@gmail.com
}

\author{
Fahriyah \\ Doctoral Student at Department of Administration Science \\ University of Brawijaya \\ Malang, Indonesia \\ fahriyah19@student.ub.ac.id
}

\author{
Yanuastrid Shintawati \\ Lecturer at Department of Library Science \\ University of Wijaya Kusuma Surabaya \\ Surabaya, Indonesia \\ yanuastrid@uwks.ac.id
}

\begin{abstract}
Modern interior design is currently following the trend of contemporary styles that utilize the entire library room to function optimally as a place to find collections, reading areas, discussions, seminars, entertainment, and learning. The research objective was to determine the perceptions of users on modern interior design at the University of Surabaya (Ubaya) Library. The research method is descriptive quantitative with a single variable Modern Interior Design Library and sub-variables include openness, multifunctional, flexibility, artistry. The study population was the average visitor visits per day of 365 people and a valid sample of 62 respondents. The sampling technique uses nonprobability sampling and purposive sampling. Data collection through online questionnaires, documentation, and literature study. Data analysis by editing, coding, and tabulating steps in the form of descriptive statistics with the help of Microsoft Excel. The results showed that the Perceptions of Users towards Modern Interior Design in the Ubaya Library is very good value with the highest percentage of $51.6 \%$. Most of the library users like the modern interior design of the library for open access to a variety of information, the existence of various spaces for various activity functions, spatial design arrangement, furniture, flexible collections, and the art of interior and exterior design of the library building. There is still a need for clear instructions/signs for library users so that they can access various information easily, quickly, accurately, and with quality.
\end{abstract}

Keywords—perception of users, design interior, college libraries

\section{INTRODUCTION}

Librarians today need to think about the situation and condition of the digital age society. The progress in the field of information technology cannot be denied that it will be one of the main drivers of the birth of a digital library. The idea of the birth of a digital library has made most librarians aware of changing the way they work in managing information sources. The information technology revolution and changes in the behavior of the user community in using information raise various challenges and obstacles faced in the development and development of libraries. Therefore, began to think about slowly changing the library building and the layout of the room so that it could be adjusted to the conditions and advances in information technology today.

The convenience of visitors so that they feel at home in the library is the main concern so that they want to visit the library room even if they are just sitting or reading casually. A library room that has a layout, furniture, room conditioning, air circulation control, lighting, and the use of character and comfortable wall paint colors will people place to stop by. Likewise, the reading room layout design has the potential to spark a reading interest in digital culture. Because the presence of digital culture allows people to read at any place and time. It is hoped that in the future it is necessary to make a library building that is comfortable for reading or to rearrange the building and layout of the library if you do not want the library to be increasingly deserted.

Suptandar in Yanuarista [1] defines interior design as the work of an architect/design which specifically concerns the inside of a building, its forms are in line with developments in science and technology which in the design process are always filled with local geographic elements and habits. social embodied in contemporary styles. Meanwhile, according to Ching [2]:

"Design is the planning, layout, and design of the interior spaces within buildings Interior. These physical settings satisfy 
our basic need for shelter and protection, set the stage for and influence the shape of our activities, nurture our aspirations, express the ideas that accompany our actions, and affect our outlook, mood, and personality. The purpose of interior design, therefore, is the functional improvement, aesthetic enrichment, and psychological enhancement of the quality of life in interior space 2

According to Eka Setyawan [3] in Progress 2: Theory and Concept of Interior Design states that: "The modern minimalist concept is a modern interior that prioritizes the function or effectiveness as well as the economic factor of its users so that the use of ornaments is very minimal or not even used at all because they mostly play with geometric fields. Apart from that, the limited land and space in urban areas, as well as the changing lifestyle of a person are also factors driving the emergence of this concept. The advantages of this concept are in the design and selection of economical materials. While the shortcomings are visible from the quality of the workmanship, if the workers are less skilled in finishing techniques then the impression that will be generated will be less good, less precise, and look rough" (28 September 2017).

Choy and Goh [4], states that "today's libraries must be a wider and deeper source than ever, a place where traditional and modern science resources, instructors and students can meet in a continuous process of learning, teaching and discovery. It doesn't take much real estate but just rethinking how the library space is used."

Yunliang [5] states that a modern library building that can operate must have principles, including: (1) Openness, that is, libraries must start providing services that are free, comfortable, and fast to users, modern libraries that are open nature without any gaps between readers and books in the library, and make users feel comfortable in the library. (2) Multifunctional, namely the arrangement of a library building so that it can function optimally not only as a place to read but also to carry out other activities in the library such as holding seminars, book reviews, watching movies, as a place for teaching and learning, as a place for research. and a place to store books and various kinds of audiovisual information, an internet room, and a special room as a place for lectures, academic seminars, and so on. (3) Flexibility, namely the construction of a library building that is designed and built in such a way that the arrangement of the room is under the arrangement of tables and chairs, bookshelves, the height of the room, and the librarian's workplace so that it can function optimally and save space at the same time simultaneously. Good lighting and ventilation arrangements will make users feel at home and comfortable using the library. (4) Artistry, namely the construction of a modern library building must present an expression of beauty in a combination of knowledge and culture. This can be displayed in the making of the interior and exterior layout of the library, the creation of an artificial natural environment in the library, or an artistic design so that it can attract visitors to linger in the library, not only reading books or looking for information but also enjoying the beautiful library design.
Ugwuanyi et al. [6] states that "a modern library building that is designed and operates with the features of openness, flexibility, multifunctional and artistry is recommended for every university. A hybrid library with print, audiovisual, digital resources and service is also suggested for the survival of the library as space and place in this Millenium."

Beagle in Donkai et al. [7], learning commons can be defined as a concept to utilize existing spaces in the library as a learning place equipped with facilities and infrastructure that support technological advancement and in one location that can be accessed freely and independently to support the learning process. Chan and Wong [8] also describes the concept of learning commons as an effort to provide various kinds of space and equipment (furniture) in the library to meet the needs of different users to be able to carry out various kinds of activities in the library.

The University of Surabaya is one of the universities in Surabaya which has library is very unique by applying the concept of modern interior design to its library, has printed collections, audiovisuals, and digital collections, and has multifunctional spaces that can be enjoyed by there. The purpose of this study was to determine the perceptions of the library users of the Ubaya towards the modern interior design of the library in terms of openness, multifunctionality, flexibility, and library artistry aspects.

\section{METHODS}

The research method is quantitative descriptive with a single variable Modern Interior Design Library and subvariables, namely: aspects of library openness, multifunctional, flexibility, and artistry. The study population was the average visitor visits per day as many as 365 people and the sample who successfully filled out the online questionnaire were 62 respondents from lecturers, employees, and students of the University of Surabaya from various majors, ages, semesters, and gender. The sampling technique uses nonprobability sampling and purposive sampling. Collecting data through online questionnaires, this is done because researchers cannot interact directly with users due to the COVID-19 pandemic situation, documentation, and literature study. The data analysis technique used was editing, coding, and tabulating steps in the form of descriptive statistics with the help of Microsoft Excel.

\section{RESULTS}

After the research data was received by the researcher, the data were sorted, performed reduction processed the data using descriptive statistics to determine the category value of each sub variable, and analyzed the processed data. This step is necessary because the purpose of data analysis is to compile and interpret the data that has been obtained. After the data is obtained, this section will describe the descriptive statistics of the respondent's data as follows: 
TABLE I. DESCRIPTION OF RESPONDENTS

\begin{tabular}{|l|l|c|c|c|}
\hline $\begin{array}{c}\text { Respondent } \\
\text { Identity }\end{array}$ & \multicolumn{1}{|c|}{ Information } & F & Percentage & $\begin{array}{c}\text { Cumulative } \\
\text { \% }\end{array}$ \\
\hline Gender & Male & 22 & $35,48 \%$ & $35,48 \%$ \\
& Female & 40 & $64,52 \%$ & $100,00 \%$ \\
\hline & Number & 62 & & \\
\hline Respondent & Lecturer & 1 & $01,61 \%$ & $01,61 \%$ \\
Status & Employees & 4 & $06,45 \%$ & $08,06 \%$ \\
& Undergraduate Students & 46 & $74,20 \%$ & $82,26 \%$ \\
& Graduate student & 11 & $17,74 \%$ & $100,00 \%$ \\
\hline & Number & 62 & & \\
\hline Faculty/ Unit & Pharmacy & 25 & $40,33 \%$ & $40,33 \%$ \\
Respondent & Psychology & 14 & $22,58 \%$ & $62,91 \%$ \\
& Business \& Economics & 14 & $22,58 \%$ & $85,49 \%$ \\
& Technique & 4 & $06,45 \%$ & $91,94 \%$ \\
& Medical & 1 & $01,61 \%$ & $93,55 \%$ \\
& Library & 4 & $06,45 \%$ & $100,00 \%$ \\
\hline & Number & 62 & \multicolumn{3}{|c|}{} \\
\hline
\end{tabular}

Based on table 1, the number of respondents in this study was 62 people consisting of 22 people (35.48\%) with male gender and 40 people $(64.52 \%)$ with the female gender. The highest status of respondents as undergraduate students was $74.20 \%$ and came from the Faculty of Pharmacy with the highest at $40.33 \%$, followed by the Psychology Faculty and the Faculty of Business and Economics at $22.58 \%$. This data was obtained from the results of distributing questionnaires conducted by researchers via a google form, this is because researchers cannot interact directly with users because the condition of the Ubaya Library was closed during the COVID19 pandemic.

The open space of the library (openness) in this study is a library that provides free, comfortable, and fast services to its users. Therefore, to design a library, it is currently starting to consider its function as a modern library that is open without gaps between readers and books in the library and makes users feel comfortable in the library.

In this paper, researchers use the modern interior design concept of a library according to Yunliang [5] that a modern library building must have the principles of openness, multifunctionality, flexibility, and artistry in library operations and this concept is clarified again by Ugwuanyi et al. [6]. Next, the authors describe the results of the study based on 4 (four) sub-variables, namely the perception of users of modern interior design from the aspects of openness, multifunctionality, flexibility, and artistry of the library building then finally describe the perceptions of users on the modern interior design in the Ubaya Library.

The results of the study seen from table 2 show that almost half of the respondents thought that the availability of printed collections at the Ubaya Library was classified as very good and half of the respondents also had a good opinion, namely $46.775 \%$ respectively. Nearly half of respondents said the availability of digital collections was good at $48.39 \%$. Nearly half of respondents, namely $45.16 \%$, think that open access to the reading room can be done easily, quickly, and comfortably is classified as very good. Then most of the respondents stated that the suitability of the reading room with the needs of the visitors was very good at $51.61 \%$. Based on the calculation, it is known that the users perceptions of the open space aspects of the library (openness) in this study that most of the respondents, namely $62.90 \%$ said it was very good, namely that the modern library of the Ubaya is open by providing printed and digital collections, without any gaps between librarians, readers and collections available in the library, and users feel comfortable in the library building.

TABLE II. USERS` PERCEPTION ON THE ASPECTS OF LIBRARY OPENNESS

\begin{tabular}{|c|c|c|c|c|c|c|}
\hline Information & Very Good & Good & Good Enough & Not Good & Very Not Good & Number \\
\hline Availability of print collections & $\begin{array}{c}29 \\
(46,775 \%)\end{array}$ & $\begin{array}{c}29 \\
(46,775 \%)\end{array}$ & $\begin{array}{c}4 \\
(06,45 \%)\end{array}$ & $\begin{array}{c}0 \\
(00,00 \%)\end{array}$ & $\begin{array}{c}0 \\
(00,00 \%)\end{array}$ & $\begin{array}{c}62 \\
(100,00 \%)\end{array}$ \\
\hline Availability of digital collections & $\begin{array}{c}18 \\
(29,03 \%) \\
\end{array}$ & $\begin{array}{c}30 \\
(48,39 \%) \\
\end{array}$ & $\begin{array}{c}10 \\
(16,13 \%) \\
\end{array}$ & $\begin{array}{c}4 \\
(06,45 \%) \\
\end{array}$ & $\begin{array}{c}0 \\
(00,00 \%) \\
\end{array}$ & $\begin{array}{c}62 \\
(100,00 \%)\end{array}$ \\
\hline Open access to the reading room is easy, fast and convenient & $\begin{array}{c}28 \\
(45,16 \%)\end{array}$ & $\begin{array}{c}22 \\
(35,49 \%)\end{array}$ & $\begin{array}{c}11 \\
(17,74 \%)\end{array}$ & $\begin{array}{c}1 \\
(01,61 \%)\end{array}$ & $\begin{array}{c}0 \\
(00,00 \%)\end{array}$ & $\begin{array}{c}62 \\
(100,00 \%)\end{array}$ \\
\hline The suitability of the reading room with the needs of visitors & $\begin{array}{c}32 \\
(51,61 \%)\end{array}$ & $\begin{array}{c}25 \\
(40,32 \%)\end{array}$ & $\begin{array}{c}5 \\
(08,07 \%) \\
\end{array}$ & $\begin{array}{c}0 \\
(00,00 \%)\end{array}$ & $\begin{array}{c}0 \\
(00,00 \%)\end{array}$ & $\begin{array}{c}62 \\
(100,00 \%)\end{array}$ \\
\hline User perceptions of the openness aspect & $\begin{array}{c}39 \\
(62,90 \%)\end{array}$ & $\begin{array}{c}20 \\
(32,26 \%)\end{array}$ & $\begin{array}{c}3 \\
(04,84 \%)\end{array}$ & $\begin{array}{c}0 \\
(00,00 \%)\end{array}$ & $\begin{array}{c}0 \\
(00,00 \%)\end{array}$ & $\begin{array}{c}62 \\
(100,00 \%)\end{array}$ \\
\hline
\end{tabular}

Based on table 3, it is known that almost half of the respondents think that the availability of data space and the internet is classified as very good and good, respectively $46.775 \%$. Nearly half of the respondents said the availability of educational information sources was good at $48.39 \%$. Half of the respondents stated that the availability of research information sources and multimedia and cinema-home theater rooms were very good, each at $50.00 \%$. Then some respondents said they were very good about the availability of relaxing space $(66.13 \%)$ and the availability of discussion rooms $(64.52 \%)$. For the availability of print space, scan, photocopy, almost half of the respondents, $45.16 \%$, are classified as very good. The availability of open stage space, almost half of respondents $38.70 \%$ said it was good, while the availability of cafe and minibar space, almost half of respondents $33.87 \%$ said it was good enough. Based on the calculation, it is known that the users' perceptions of the multifunctional aspects of the library stated that most of the respondents, namely $54.84 \%$ said it was very good, namely the modern Ubaya Library has a maximum function as a place to 
read, hold seminars, book reviews, discussions, watch movies

together, and study teaching/lectures, research sites, and so on.

TABLE III. USERS’ PerCEPTION ON THE ASPECTS OF LibRARY MULTIFUNCTIONAL

\begin{tabular}{|c|c|c|c|c|c|c|}
\hline Information & Very Good & Good & Good Enough & Not Good & Very Not Good & Number \\
\hline Availability of data and internet space & $\begin{array}{c}29 \\
(46,775 \%)\end{array}$ & $\begin{array}{c}29 \\
(46,775 \%)\end{array}$ & $\begin{array}{c}4 \\
(06,45 \%) \\
\end{array}$ & $\begin{array}{c}0 \\
(00,00 \%) \\
\end{array}$ & $\begin{array}{c}0 \\
(00,00 \%)\end{array}$ & $\begin{array}{c}62 \\
(100,00 \%) \\
\end{array}$ \\
\hline Availability of educational information sources / teaching & $\begin{array}{c}18 \\
(29,03 \%)\end{array}$ & $\begin{array}{c}30 \\
(48,39 \%)\end{array}$ & $\begin{array}{c}10 \\
(16,13 \%)\end{array}$ & $\begin{array}{c}4 \\
(06,45 \%)\end{array}$ & $\begin{array}{c}0 \\
(00,00 \%)\end{array}$ & $\begin{array}{c}62 \\
(100,00 \%)\end{array}$ \\
\hline Availability of research information sources & $\begin{array}{c}31 \\
(50,00 \%)\end{array}$ & $\begin{array}{c}24 \\
(38,70 \%)\end{array}$ & $\begin{array}{c}6 \\
(09,69 \%)\end{array}$ & $\begin{array}{c}0 \\
(00,00 \%)\end{array}$ & $\begin{array}{c}1 \\
(01,61 \%)\end{array}$ & $\begin{array}{c}62 \\
(100,00 \%)\end{array}$ \\
\hline Availability of multimedia and cinema-home theater rooms & $\begin{array}{c}31 \\
(50,00 \%)\end{array}$ & $\begin{array}{c}25 \\
(40,32 \%)\end{array}$ & $\begin{array}{c}4 \\
(06,45 \%)\end{array}$ & $\begin{array}{c}2 \\
(03,23 \%)\end{array}$ & $\begin{array}{c}0 \\
(00,00 \%)\end{array}$ & $\begin{array}{c}62 \\
(100,00 \%)\end{array}$ \\
\hline Availability of relaxing space & $\begin{array}{c}41 \\
(66,13 \%)\end{array}$ & $\begin{array}{c}19 \\
(30,64 \%)\end{array}$ & $\begin{array}{c}2 \\
(03,23 \%)\end{array}$ & $\begin{array}{c}0 \\
(00,00 \%)\end{array}$ & $\begin{array}{c}0 \\
(00,00 \%)\end{array}$ & $\begin{array}{c}62 \\
(100,00 \%)\end{array}$ \\
\hline Availability of open stage & $\begin{array}{c}17 \\
(27,43 \%)\end{array}$ & $\begin{array}{c}24 \\
(38,70 \%)\end{array}$ & $\begin{array}{c}19 \\
(30,65 \%)\end{array}$ & $\begin{array}{c}1 \\
(01,61 \%)\end{array}$ & $\begin{array}{c}1 \\
(01,61 \%)\end{array}$ & $\begin{array}{c}62 \\
(100,00 \%)\end{array}$ \\
\hline Availability of discussion rooms & $\begin{array}{c}40 \\
(64,52 \%)\end{array}$ & $\begin{array}{c}18 \\
(29,03 \%)\end{array}$ & $\begin{array}{c}4 \\
(06,45 \%)\end{array}$ & $\begin{array}{c}0 \\
(00,00 \%)\end{array}$ & $\begin{array}{c}0 \\
(00,00 \%)\end{array}$ & $\begin{array}{c}62 \\
(100,00 \%)\end{array}$ \\
\hline Availability of cafe space and mini bar & $\begin{array}{c}8 \\
(12,90 \%)\end{array}$ & $\begin{array}{c}9 \\
(14,52 \%)\end{array}$ & $\begin{array}{c}21 \\
(33,87 \%)\end{array}$ & $\begin{array}{c}13 \\
(20,97 \%)\end{array}$ & $\begin{array}{c}11 \\
17,74 \%)\end{array}$ & $\begin{array}{c}62 \\
(100,00 \%)\end{array}$ \\
\hline Availability of print, scan, photocopy space & $\begin{array}{c}28 \\
(45,16 \%)\end{array}$ & $\begin{array}{c}20 \\
(32,26 \%)\end{array}$ & $\begin{array}{c}11 \\
(17,74 \%)\end{array}$ & $\begin{array}{c}3 \\
(04,84 \%)\end{array}$ & $\begin{array}{c}0 \\
(00,00 \%)\end{array}$ & $\begin{array}{c}62 \\
(100,00 \%)\end{array}$ \\
\hline
\end{tabular}

Based on table 4, it is known that most respondents think that the arrangement of library furniture is very good at $51.61 \%$. Half of the respondents, namely $50.00 \%$ stated that the room temperature regulation in the library building was very good. Then the librarian workspace arrangement of $43.55 \%$ is classified as very good and $43.55 \%$ also has a good opinion. Then half of the respondents, as much as $50.00 \%$, stated that the arrangement of the collection room and reading area for the visitors was good. For the arrangement of light in the library room of $46.77 \%$, almost half of the respondents said it was good. Based on the calculation, it is known that the perception of the library users on the aspects of library flexibility states that almost half of the respondents, namely $48.39 \%$ are classified as very good and $48.39 \%$ also say that it is good for arranging furniture, tables, chairs, bookshelves, room temperature regulation, librarian workspace arrangement, the arrangement of the collection room as well as the arrangement of lighting inside and outside the Ubaya Library building which makes users feel at home and comfortable using the library.

TABLE IV. USERS' PERCEPTION ON THE ASPECTS OF LIBRARY FLEXIBILITY

\begin{tabular}{|c|c|c|c|c|c|c|}
\hline Information & Very Good & Good & Good Enough & Not Good & Very Not Good & Number \\
\hline Librarian workspace & $\begin{array}{c}27 \\
(43,55 \%)\end{array}$ & $\begin{array}{c}27 \\
(43,55 \%)\end{array}$ & $\begin{array}{c}7 \\
(11,29 \%) \\
\end{array}$ & $\begin{array}{c}1 \\
(01,61 \%)\end{array}$ & $\begin{array}{c}0 \\
(00,00 \%) \\
\end{array}$ & $\begin{array}{c}62 \\
(100,00 \%)\end{array}$ \\
\hline Library layout & $\begin{array}{c}32 \\
(51,61 \%)\end{array}$ & $\begin{array}{c}24 \\
(38,70 \%)\end{array}$ & $\begin{array}{c}6 \\
(09,69 \%)\end{array}$ & $\begin{array}{c}0 \\
(00,00 \%)\end{array}$ & $\begin{array}{c}0 \\
(00,00 \%)\end{array}$ & $\begin{array}{c}62 \\
(100,00 \%)\end{array}$ \\
\hline Collection layout and reading area & $\begin{array}{c}23 \\
(37,10 \%)\end{array}$ & $\begin{array}{c}31 \\
(50,00 \%)\end{array}$ & $\begin{array}{c}7 \\
(11,29 \%)\end{array}$ & $\begin{array}{c}1 \\
(01,61 \%)\end{array}$ & $\begin{array}{c}0 \\
(00,00 \%)\end{array}$ & $\begin{array}{c}62 \\
(100,00 \%)\end{array}$ \\
\hline Room lighting & $\begin{array}{c}23 \\
(37,10 \%)\end{array}$ & $\begin{array}{c}29 \\
(46,77 \%)\end{array}$ & $\begin{array}{c}10 \\
(16,13 \%) \mathrm{P}\end{array}$ & $\begin{array}{c}0 \\
(00,00 \%)\end{array}$ & $\begin{array}{c}0 \\
(00,00 \%)\end{array}$ & $\begin{array}{c}62 \\
(100,00 \%)\end{array}$ \\
\hline Room temperature setting & $\begin{array}{c}31 \\
(50,00 \%)\end{array}$ & $\begin{array}{c}26 \\
(41,93 \%)\end{array}$ & $\begin{array}{c}5 \\
(08,07 \%) \\
\end{array}$ & $\begin{array}{c}0 \\
(00,00 \%)\end{array}$ & $\begin{array}{c}0 \\
(00,00 \%)\end{array}$ & $\begin{array}{c}62 \\
(100,00 \%)\end{array}$ \\
\hline User perceptions on aspects of flexibility & $\begin{array}{c}30 \\
(48,39 \%)\end{array}$ & $\begin{array}{c}30 \\
(48,39 \%)\end{array}$ & $\begin{array}{c}2 \\
(03,22 \%)\end{array}$ & $\begin{array}{c}0 \\
(00,00 \%)\end{array}$ & $\begin{array}{c}0 \\
(00,00 \%)\end{array}$ & $\begin{array}{c}62 \\
(100,00 \%)\end{array}$ \\
\hline
\end{tabular}

Based on table 5, it is known that most respondents think very well in terms of users feeling at home and comfortable in the library $(54.84 \%)$, the appearance of the color of the library walls $(54.84 \%)$, the appearance of the art of interior and exterior design of the library (51.61\%). As for the art of color combinations of tables and chairs in the library, almost half of the respondents, namely $48.39 \%$ said it was very good. While the appearance of the library building as a form of source of knowledge, almost half of the respondents, namely $45.16 \%$, were classified as very good. Then the appearance of the library building which presents the form of national cultural arts, almost half of the respondents, namely $40.32 \%$ said it was good. Based on the calculation, it is known that the perception of the library users on the aspects of library artistry states that most of the respondents, namely $62.90 \%$ for the expression of beauty or art of the library building, are classified as very good at combining knowledge and Indonesian culture. The creation of artificial natural environments or artistic designs at the 
Ubaya Library has attracted visitors to linger in the library, not only reading books or looking for information but also being able to enjoy the beautiful library designs.

TABLE V. USERs’ PERCEPTION ON THE ASPECTS OF LIBRARY ARTISTRY

\begin{tabular}{|c|c|c|c|c|c|c|}
\hline Information & Very Good & Good & Good Enough & Not Good & Very Not Good & Number \\
\hline Interior and exterior design views & $\begin{array}{c}32 \\
(51,61 \%) \\
\end{array}$ & $\begin{array}{c}25 \\
(40,32 \%) \\
\end{array}$ & $\begin{array}{c}3 \\
(04,84 \%) \\
\end{array}$ & $\begin{array}{c}2 \\
(03,23 \%) \\
\end{array}$ & $\begin{array}{c}0 \\
(00,00 \%) \\
\end{array}$ & $\begin{array}{c}62 \\
(100,00 \%) \\
\end{array}$ \\
\hline Building views as a source of knowledge & $\begin{array}{c}28 \\
(45,16 \%) \\
\end{array}$ & $\begin{array}{c}24 \\
(38,71 \%) \\
\end{array}$ & $\begin{array}{c}9 \\
(14,52 \%) \\
\end{array}$ & $\begin{array}{c}1 \\
(01,61 \%) \\
\end{array}$ & $\begin{array}{c}0 \\
(00,00 \%) \\
\end{array}$ & $\begin{array}{c}62 \\
(100,00 \%) \\
\end{array}$ \\
\hline The building appearance presents national culture & $\begin{array}{c}21 \\
(33,87 \%)\end{array}$ & $\begin{array}{c}25 \\
(40,32 \%)\end{array}$ & $\begin{array}{c}14 \\
(22,58 \%)\end{array}$ & $\begin{array}{c}2 \\
(03,23 \%)\end{array}$ & $\begin{array}{c}0 \\
(00,00 \%)\end{array}$ & $\begin{array}{c}62 \\
(100,00 \%)\end{array}$ \\
\hline Room wall color display & $\begin{array}{c}34 \\
(54,84 \%)\end{array}$ & $\begin{array}{c}17 \\
(27,42 \%)\end{array}$ & $\begin{array}{c}11 \\
(17,74 \%)\end{array}$ & $\begin{array}{c}0 \\
(00,00 \%)\end{array}$ & $\begin{array}{c}0 \\
(00,00 \%)\end{array}$ & $\begin{array}{c}62 \\
(100,00 \%)\end{array}$ \\
\hline Color combination of table and chairs & $\begin{array}{c}30 \\
(48,39 \%) \\
\end{array}$ & $\begin{array}{c}23 \\
(37,09 \%) \\
\end{array}$ & $\begin{array}{c}9 \\
(14,52 \%)\end{array}$ & $\begin{array}{c}0 \\
(00,00 \%) \\
\end{array}$ & $\begin{array}{c}0 \\
(00,00 \%) \\
\end{array}$ & $\begin{array}{c}62 \\
(100,00 \%) \\
\end{array}$ \\
\hline Users feel at home and comfortable & $\begin{array}{c}34 \\
(54,84 \%)\end{array}$ & $\begin{array}{c}24 \\
(38,71 \%)\end{array}$ & $\begin{array}{c}4 \\
(06,45 \%)\end{array}$ & $\begin{array}{c}0 \\
(00,00 \%)\end{array}$ & $\begin{array}{c}0 \\
(00,00 \%)\end{array}$ & $\begin{array}{c}62 \\
(100,00 \%)\end{array}$ \\
\hline User perceptions on aspects of artistry & $\begin{array}{c}39 \\
(62,90 \%)\end{array}$ & $\begin{array}{c}19 \\
(30,65 \%)\end{array}$ & $\begin{array}{c}4 \\
(06,45 \%)\end{array}$ & $\begin{array}{c}0 \\
(00,00 \%)\end{array}$ & $\begin{array}{c}0 \\
(00,00 \%)\end{array}$ & $\begin{array}{c}62 \\
(100,00 \%)\end{array}$ \\
\hline
\end{tabular}

The results of research on user perceptions of modern interior design at the Ubaya Library show that most of the respondents or around $51,61 \%$ stated very good which can be seen from table 6 below.

TABLE VI. USERS' PERCEPTION OF THE MODERN INTERIOR DESIGN OF THE LIBRARY

\begin{tabular}{|c|c|c|c|c|c|c|}
\hline The Perception of Users & Very Good & Good & Good Enough & Not Good & Very Not Good & Number \\
\hline Openness aspect & $\begin{array}{c}39 \\
(62,90 \%)\end{array}$ & $\begin{array}{c}20 \\
(32,26 \%)\end{array}$ & $\begin{array}{c}3 \\
(04,84 \%)\end{array}$ & $\begin{array}{c}0 \\
(00,00 \%)\end{array}$ & $\begin{array}{c}0 \\
(00,00 \%)\end{array}$ & $\begin{array}{c}62 \\
(100,00 \%)\end{array}$ \\
\hline Multifunctional aspect & $\begin{array}{c}34 \\
(54,84 \%)\end{array}$ & $\begin{array}{c}26 \\
(41,94 \%)\end{array}$ & $\begin{array}{c}2 \\
(03,22 \%)\end{array}$ & $\begin{array}{c}0 \\
(00,00 \%)\end{array}$ & $\begin{array}{c}0 \\
(00,00 \%)\end{array}$ & $\begin{array}{c}62 \\
(100,00 \%)\end{array}$ \\
\hline Flexibility aspect & $\begin{array}{c}30 \\
(48,39 \%)\end{array}$ & $\begin{array}{c}30 \\
(48,39 \%)\end{array}$ & $\begin{array}{c}2 \\
(03,22 \%)\end{array}$ & $\begin{array}{c}0 \\
(00,00 \%)\end{array}$ & $\begin{array}{c}0 \\
(00,00 \%)\end{array}$ & $\begin{array}{c}62 \\
(100,00 \%)\end{array}$ \\
\hline Artistry aspect & $\begin{array}{c}39 \\
(62,90 \%)\end{array}$ & $\begin{array}{c}19 \\
(30,65 \%)\end{array}$ & $\begin{array}{c}4 \\
(06,45 \%)\end{array}$ & $\begin{array}{c}0 \\
(00,00 \%)\end{array}$ & $\begin{array}{c}0 \\
(00,00 \%)\end{array}$ & $\begin{array}{c}62 \\
(100,00 \%)\end{array}$ \\
\hline Total Design Interior Modern & $\begin{array}{c}32 \\
(51,61 \%)\end{array}$ & $\begin{array}{c}29 \\
(46,78 \%)\end{array}$ & $\begin{array}{c}1 \\
(01,61 \%)\end{array}$ & $\begin{array}{c}0 \\
(00,00 \%)\end{array}$ & $\begin{array}{c}0 \\
(00,00 \%)\end{array}$ & $\begin{array}{c}62 \\
(100,00 \%)\end{array}$ \\
\hline
\end{tabular}

\section{DISCUSSION}

University libraries should be designed and designed by considering the functions, uses, and attractiveness of all elements of the higher education academic community. The psychological aspects that use the library must also be considered, especially the art of interior and exterior design of the library space and building. The principles of openness, multifunctionality, flexibility, and artistry in library operations on modern library interior design according to Yunliang [5] were further clarified by Ugwuanyi et al. [6] has been implemented by the Ubaya Library. From the results of the research that has been carried out and the analysis of the results of the research, it can be concluded that the Perception of Users on the Modern Interior Design in the University of Surabaya Library are as follows:

- Perception of Library Openness shows that $62.90 \%$ have stated that the Ubaya Library has a very good value, namely having an openness between readers and books in the library, between librarians and visitors, and providing free, comfortable services and fast to its users. Thus it can be concluded that the openness in the Library of the University of Surabaya has been carried out very well with the provision of collections in the form of text and digital books and the ease with which visitors can access the library collections and the existence of a reading area that suits the needs and desires of the readers.

- Perception of Library Multifunctional shows that $54.84 \%$ stated that the Ubaya Library has a very good value, namely having a multifunctional nature, namely that the library is not only a place to read but also functions for other activities such as seminars, book reviews, watching movies, etc. Thus, it can be concluded that the Ubaya Library Multifunctional has been carried out very well with the provision of data rooms (self-access) and internet facilities/services through available computing devices. Libraries also provide sources of information that can assist the education, teaching, and research process on campus. The Ubaya Library also provides a multimedia room and cinema theater, a lesehan room, an open stage, a 
discussion room, a break room in the form of a café, and a minibar and provides an area for printing, scanning, and photocopying.

- Perception of Library Flexibility shows that $48.39 \%$ stated that the Ubaya Library has a very good value, namely as a library that has a flexible nature where the Ubaya Library is built in such a way, the room arrangement is by the librarian's work description, the arrangement of tables and chairs, bookshelves, and room heights that match modern architecture so they can function optimally and save space at the same time. Light regulation, both natural and artificial, and centrally regulating room temperature (AC) can make library visitors feel comfortable.

- Perception of Library Artistry shows that $62.90 \%$ stated that the Ubaya Library has a very good value, namely as a library that has artistic properties where the Ubaya Library is built in such a way with a modern interior design that makes room arrangements to display expressions of beauty and a combination of knowledge and culture, to attract visitors to linger in the library. Thus it can be concluded that the artistry at the Ubaya Library has performed very well in the appearance of its interior and exterior designs, and can present themselves as a source of beautiful and interesting knowledge so that visitors feel at home and comfortable in the library space.

- Users' perceptions of modern interior design at the Ubaya Library have the highest percentage of $51.61 \%$ with a very good category as a modern library that can be used as a source of knowledge with various collections in the form of text and digital collections. Also, the interior and exterior design of the library space is more modern and dynamic, equipped with various areas to carry out activities that are useful in supporting science and make the wearer feel at home and comfortable to linger in the library. However, there is still a need for clear directions/signs for library users to be able to access various information easily, quickly, accurately, and with quality at the Ubaya Library building.

\section{CONCLUSION}

The world of digital information in this century has influenced the development of interior and exterior forms of university library buildings and spaces. Collaboration between librarians, architects, and library users is needed to produce a modern interior design for the library to support the achievement of the vision, mission, and goals of the parent university. The importance of librarians in designing the space or library building which prioritizes the function or effectiveness as well as the economic factors of its users. The shift in librarian duties, the development of collections from conventional to electronic and digital, changes in the function of the library space and building, developments in information and communication technology, and changes in the behavior of library users must be immediately adopted by all elements of the college library. Aspects of openness, multifunctionality, flexibility, and artistry in library operations can be recommended for the modern interior design of libraries, both university libraries and other types of libraries. The modern interior design of the library is very supportive of the fulfillment of the objectives of the library users, such as easy access to printed and electronic sources of information, as a place for teaching and learning, as a place and source of research information, as a place for all academic, social and entertainment activities, as a place to enjoy the beauty. library, as well as a place for the development and presentation of national culture.

\section{ACKNOWLEDGMENT}

The researchers thank the Head and the staff University of Surabaya Library, who have permitted to carry out this research during the COVID-19 pandemic.

\section{REFERENCES}

[1] D. Yanuarista, Persepsi Pemustaka tentang Desain Interior Perpustakaan Universitas Airlangga Surabaya, Surabaya: Universitas Airlangga, 2013.

[2] F.D.K. Ching, Illustrasi Design Interior, Jakarta: Airlangga, 1996

[3] E. Setyawan, Progress 2: Teori dan Konsep Desain Interior, 28 September 2017.

[4] F.C. Choy and S.N. Goh, "A framework for planning academic library spaces," Library Management, vol. 37, pp. 13-28, 2016.

[5] M.A. Yunliang, "The Development of Library Building in Shanghai," in Library Buildings in a changing environment. Bisbrouck M. Ed. Proceedings of the Eleventh Seminar of the IFLA Section on Library Buildings and Equipment, Shanghai, China, 14-18 August 1999.

[6] C.F. Ugwuanyi, R.N. Okwor and E.C. Ezwji, "Library space and place: nature, use and impact on the academic library," International Journal of Library and Information Science, vol. 3 no. 5, pp. 92-97, 2011.

[7] S. Donkai, A. Yoshimori and C. Mizoue, "Academic Libraries As Learning Spaces in Japan: Toward The Development of Learning Commons," The International Information \& Library Review, vol. 43 no. 4, pp. 215-220, December 2011.

[8] D.L.H. Chan and G.K.W. Wong, "If you build it, they will come: an intro institutional user engagement process in the learning commons,' New Library World, vol. 114 Issue 1/2 pp. 44-53, 2003. 